\title{
THE IDENTIFICATION OF GREEN BANKING CONCEPT AND BANK LIABILITY (A STUDY OF ACT NUMBER 10 OF 1998 WITH EXTENSIVE INTERPRETATION AND PROGRESSIVE LEGAL APPROACH)
}

\author{
ANITALIA KUSUMA DEWI \\ Student of Graduate Program of Master of Legal Science, Faculty of Law, \\ Universitas Gadjah Mada. Sosio Justitia Street. Bulaksumur Yogyakarta. \\ anitaliakusumadewi@yahoo.com. Phone 08179609845. \\ PARIPURNA \\ Lecturer at the Business Law Department. Faculty of Law, Universitas Gadjah \\ Mada. Sosio Justitia Street. Bulaksumur Yogyakarta.
}

\begin{abstract}
The purposes of this research are to analyze the identification of Green Banking concept in the Act Number 10 of 1998 with extensive interpretation and progressive legal approach and to analyze how banks should be held liable for based on applicable law in view of the extensive interpretation and progressive legal approach. This research is a normative legal research that has analyzed Green Banking concept using Act Number 10 of 1998 concerning Banking, Bank Indonesia Regulation Number 14/15/PBI/2012 concerning Asset Quality of Commercial Banks, Act Number 32 of 2009 concerning Environmental Protection and Management and the Financial Services Authority Regulation Number 51/POJK.03/2017 concerning the Application of Sustainable Finance for Financial Services Institutions, Issuer Companies and Public Companies, and then presented as prescriptive research. The result of this study is that banks are reluctant to further examine the AMDAL of financed projects and do not oversee such projects until the termination of the contract. Extensive interpretation and progressive legal approach can be used to provide bank a deep insight regarding the concept of green banking contained in the banking law and the extent to which banks (creditors) are subject to the terms of the lender liability.
\end{abstract}

Keywords: Green Banking, Bank Liability, Extensive Interpretation, Progressive Legal Approach.

\section{UNDERLYING BACKGROUND AND CONTEXT}

Bank as a financial institution and one of the pillars of Indonesian economy 
that provides funds for development shall also support sustainable and environmentally sound development as set forth in Act Number 10 of 1998 concerning Banking. With such significant bank position, banks should be selective in channeling funds into non-destructive business activities. One of the business activities is oil palm plantation which has recently been highlighted because of getting involved in deforestation, land clearing, peat burned, the extinction of biodiversity, violation of local society's rights, illegally planting on the burned peat lands that should be restored, social conflict with local communities are not being addressed, as the company promised they would be, violating the agreement and policy by the company itself, and so on. Some further questions are, who should bear the risks of such business activities that have committed to burning peatland for monoculture plantations, building factories, disposing of waste, pollution, etc.? Is the defendant who has engaged in such business activity whose impact is pervasive and dangerous? Is the bank as the financier or lender also responsible because the bank knows the risks of its client's business activities as it has been proven with AMDAL, UKL, UPL, KLHS before making a decision to finance)? Is the risk borne by the plaintiff who has suffered a loss?

Based on the data from Forests and Finance, $2016^{1}$, there are so many banks indirectly involved through their significant role as financier, lender, and/or shareholder in case of financing the oil palm plantation company that expanding its concession by developing palm oil on prohibited areas such as peat lands, destructing environment, and allowing forest fires. It shows that the voluntary policies (such as NDPE - No Deforestation, No Peat and No Exploitation) of the company and its financier cannot be trusted. They are, among others, of the stateowned banks, private banks, and foreign banks as follows: (1) CIMB (Malaysia); (2) HSBC (United Kingdom); (3) Mizuho Financial (Japan); (4) DBS (Singapore); (5) OCBC (Singapore); (6) Standard Chartered (United Kingdom); (7) JP Morgan Chase (United States); (8) Credit Suisse (Switzerland); (9) Deutsche Bank

Forests and Finance. The Banks and Investors Exposed to Deforestation Risks in Southeast Asia, 2010-2015. http://forestsandfinance.org/ Accessed on January 24, 2017. 
(Germany); (10) Bank Mandiri (Indonesia); (11) Morgan Stanley (United States); (12) Sumitomo Mitsui (Japan); (13) BNI (Indonesia); (14) Citigroup (United States); (15) Rabobank (Netherlands); (16) BRI (Indonesia); (17) ANZ (Australia).

Whereas, some of those banks are members of Equator Principles. ${ }^{2}$ They are among others, Mizuho (Japan), Sumitomo Mitsui (Japan), HSBC (United Kingdom), Standard Chartered (United Kingdom), JP Morgan Chase (United States), ABN Amro (The Netherlands), Credit Suisse (Switzerland), Citigroup (United States), Australia and New Zealand Banking Group Limited (Australia), ${ }^{3}$ and so on. In the context of sustainable finance, financial institutions are the main and determining sector for sustainability itself. Bank financing is still slightly concerned with environmental issues and tends to ignore legal risks, environmental risks, credit risks, and reputation risks that could threaten the sustainability of bank itself.

In this research, the author cited lender liability under CERCLA (as has been amended to SARA) that has been applied in the United States. This is not to compare with but in order to strengthen the lender liability theory in Indonesia because so far the bank as a lender to the company getting involved in environmental destruction cannot be held liable due to the reasons of bank secrecy, no court decision, and so on. Regrettably, in 2015, the losses have impinged on the environment and society such as forest fires on peat lands, therefore, the imposition of lender liability on banks should be reaffirmed in order to force the financial institutions to take environmental impact into account in making an investment and financing decisions.

Based on the aforementioned description, the research questions are focused on as follows: (1) How does the identification of Green Banking

2 The Equator Principles is a risk management framework, adopted by financial institutions, for determining, assessing, and managing environmental and social risk in projects. Cited from http://www.equator-principles.com/. Accessed on April 11, 2017.

3 See The Banks and Investors Exposed to Deforestation Risks in Southeast Asia. 2016. http://forestsandfinance.org/ and Equator Principles Association Members and Reporting. 2011. http://www.equator-principles.com/index.php/members-and-reporting. Accessed on April 12, 2017. 
concept in the Act Number 10 of 1998 in view of extensive interpretation and progressive legal approach? (2) Based on such identification, how should the bank be held liable for based on the applicable law in view of extensive interpretation and progressive legal approach?

\section{RESEARCH METHODS}

\section{Type of Research}

Focusing on research questions, then this research is a normative legal research. According to Soerjono Soekanto ${ }^{4}$ that processing, analysis, and construction of normative legal research data including research on legal principles, analyze on systematic of legislation, research on the standard of legislation synchronization, legal comparison, and legal history. Legal research studies the applicable rules, through analysis of treaties, legislation, case law, and literature. It employed several approaches, i.e. conceptual approach ${ }^{5}$ and statutory approach, then presented as prescriptive research ${ }^{6}$. As a prescriptive science, the legal science studies the purpose of law, values of justice, the validity of the legal regulation, the concepts of law, and legal norms. ${ }^{7}$

\section{Scope of the Research}

This research will analyze the identification of Green Banking concept and bank liability due to the environmental destruction caused by its clients, such as some oil palm plantation companies. Both concepts will be analyzed by using the legal perspective of Act Number 10 of 1998 concerning Banking, Bank Indonesia Regulation Number 14/15/PBI/2012 concerning Assessment of Commercial Bank Asset Quality, Financial Services Authority Regulation Number 51/POJK.03/2017 concerning The Application of Sustainable Finance for

4 Soerjono Soekanto. 1986. Pengantar Penelitian Hukum. Penerbit Universitas Indonesia (UI-Press). Jakarta. Page 252-256.

5 Although not explicitly, the concept of law can also be found in the regulation. Only in identifying the principle, the researcher first understands the concept through existing views and doctrines. (see Peter Mahmud Marzuki. 2007. Penelitian Hukum. Kencana. Jakarta. Page 138).

6 According to Peter Mahmud Marzuki, for the purpose of writing academic work, the output of a legal research is prescriptions in the form of recommendations or suggestions. Ibid. page 41.

7 Ibid. page 171. 
Financial Services Institutions, Issuer Companies and Public Companies and Act Number 32 of 2009 concerning Environmental Protection and Management in view of extensive interpretation and progressive legal approach. The extensive interpretation and progressive legal approach are used in this research because the Act Number 32 of 2009 concerning the Environmental Protection and Management in Article 1 Point 32 states that "Everybody shall be individual or business entity whether in the form of legal entity or not." It is clear that such provision includes the bank as well.

\section{Source of Legal Materials}

According to this type of research, as a library-based research, it will be sourced and collected from publicly available information including legislation and/or regulations, scientific articles, literature, annual reports, journal, and official documentation of various organizations and projects.

a) Primary law materials, which are legally binding and authoritative existing national laws of the Republic of Indonesia, such as Act Number 10 of 1998 concerning Banking, Bank Indonesia Regulation Number 14/15/PBI/2012 concerning Assessment of Commercial Bank Asset Quality, Financial Services Authority Regulation Number 51/POJK.03/2017 concerning The Application of Sustainable Finance for Financial Services Institutions, Issuer Companies and Public Companies and Act Number 32 of 2009 concerning Environmental Protection and Management, Act Number 12 of 2011 concerning Formulation of Regulatory Legislation, and Financial Service Authority Regulation Number 18/POJK/03/2016 concerning Implementation of Banking Risk Management.

b) Secondary law materials, literary documents concerning with recent knowledge of facts or materials providing explanations for the primary law materials (primary legal documents) sourced from books, journals, progress report, working paper, Black's Law Dictionary, and any kind of publications related to the subject matter.

\section{Analysis of Legal Materials}

This research aims for a legal discovery which has been analyzed by using the 
extensive interpretation and progressive legal approach. Analyzing the legal materials in this study, beginning with:

1. identifying the legal facts to determine the legal issues to be solved,

2. collecting legal materials (primary and secondary),

3. conduct a review of legal issues submitted based on legal materials that have been collected,

4. formulate conclusions in the form of arguments to answer legal issues,

5. provide prescriptions based on conclusions.

\section{RESEARCH RESULT AND DISCUSSION}

1. The Extensive Interpretation and Progressive Judge Decision of Mandalawangi Case, Precautionary Principle, and Strict Liability

One of the implementations of a progressive legal theory was conducted by the judge of Bandung District Court in the case of compensation caused by the landslide of Mount Mandalawangi in 2004. The judge decision of the Bandung District Court in adjudicating the compensation case due to landslide of Mount Mandalawangi in 2004 long before the enactment of Act Number 32 of 2009, whereas the Act Number 23 of 1997 concerning Environmental Management limited Strict Liability only to the management of hazardous and toxic materials and wastes. This proves that judges have extended the implementation of strict liability by classifying the management of protected forests as extra hazardous or unusual. In understanding the law, the judge should not only read the legal texts but must pay attention to the causes (history), the intent and purpose of the legal regulation, as well as the interconnection of one legal regulation with the other legal regulations. ${ }^{8}$ In their judgment, the judges base the implementation of strict liability contained in the Principle 15 of 1992 Rio Declaration. ${ }^{9}$

8 Imammulhadi. Perkembangan Prinsip Strict Liability dan Precautionary dalam Penyelesaian Sengketa Lingkungan Hidup di Pengadilan. Mimbar Hukum. Volume 25, No.3. October 2013. Page 426-427. https://jurnal.ugm.ac.id/jmh/article/viewFile/16070/10616. accessed on July 13, 2017.

9 Rio Declaration on Environment and Development in Principle 15 stipulates that "In order to protect the environment, the precautionary approach shall be widely applied by States according to their capabilities. Where there are threats of serious or irreversible damage, lack of full scientific certainty shall not be used as a reason for postponing cost-effective measures to prevent environmental degradation." Report of The United Nations 
Previously defendants often escaped from the demands of compensation, because judges when confronted with doubt always apply the principle of in dubio pro reo as a guide. Along with the paradigm shift from homo-centric to ecocentric then in the environmental justice, the principle of in dubio pro reo changed into the principle of in dubio pro natura. ${ }^{10}$ The progressive court decision of the Mandalawangi case had been an impetus for the development of new legal rules and more precise principles. One of the solutions to environmental law reform is the enactment of Act Number 32 of 2009 concerning Environmental Protection and Management.

With the enactment of Act Number 32 of 2009 can the banking law be getting more pro-environment in running the banking business? This is why we need to apply an extensive interpretation of Act Number 10 of 1998 which is still vague when it comes to adjusting to the latest developments, particularly those related to a high-risk project financing and the large-scale impact on the environment. With the extensive interpretation than simply grammatical insights, it remains within the law itself, does not ignore the legal regulation, legal justice, the purposiveness, and legal certainty. An extensive interpretation is carried out because the existing laws or regulations are obscure and obsolete to fulfill the values that live in society.

\section{The Concept of Green Banking and Lender Liability under the Indonesian} Banking Law through Extensive Interpretation and Progressive Legal Approach

In order to improve the significant role of the lender (bank) in mitigating environmental destruction that may be committed by its client, the following provisions should be interpreted extensively and progressively:

\section{Elucidation of the Act Number 10 of 1998 concerning Banking at the fifth}

Conference on Environment and Development. Rio de Janeiro, 3-14 June 1992. General Assembly. United Nations. A/CONF.151/26 (Vol.I). http://www.un.org/documents/ga/conf151/aconf15126-1annex1.htm. accessed on July 14, 2017.

10 Imammulhadi. op.cit. Page 429. In dubio pro natura means that if in doubt, decide in favor of the environment. This philosophy or doctrine was made by ancient Roman thinkers in the field of law. Cited from Leonard Tiopan Panjaitan. 2015. Bank Ramah Lingkungan. Penebar Plus. Jakarta. Page 25-26. 
paragraph explained that, "Prudential Principles must have adhered consistently, meanwhile the regulations on bank activities have to be improved especially those relating to the extension of funds, including the increasing role of an Analysis on the Environmental Impact (AMDAL) for big scale company or high-risk company."

2. Act Number 10 of 1998 concerning Banking in Article 29 Paragraph 2 states that:

A bank shall maintain its soundness in accordance with the provisions concerning the adequacy of capital, quality of assets, quality of management, liquidity, profitability, solvency, and other aspects related to the operations of a bank, and shall be required to conduct operations in accordance with the prudential principle.

\section{The last paragraph of Elucidation of Article 8 Paragraph 1 of Act Number} 10 of 1998 concerning Banking, states that, "In addition, in the extension of credit or financing based on sharia principles, the bank shall take into account the result of Analysis concerning the environmental impact (AMDAL) for big scale companies and/or high risk, so that the project being financed protects the sustainability of the environment."

4. Elucidation of Article 8 Paragraph 2b of Act Number 10 of 1998 concerning Banking stated that, "Bank shall have confidence in the capability and capacity debtor customer which, among others, obtained by an accurate appraisal of the character, capability, capital, collateral, and the business prospect of debtor customer."

5. Relating to this provision, Bank Indonesia had issued the Bank Indonesia Regulation namely PBI Number 14/15/PBI/2012 concerning Assessment of Commercial Bank Asset Quality in Article 10 states that, "Credit quality is determined based on assessment factor as follows:
a. Business prospect,
b. Debtor performance,
c. Repayment capability."

6. PBI Number 14/15/PBI/2012 concerning Assessment of Commercial Bank 
Asset Quality in the Article 11 states that:

1. Assessment of business prospect as referred to in Article 10 letter a covers assessment on the following components:

a. Potential of business growth;

b. Market condition and debtor's position in competition;

c. Management quality and human resource problems;

d. Support from group or affiliation; and

e. Efforts undertaken by the debtor in the framework of environment conservation.

2. Assessment of debtor performance as referred to in Article 10 letter b covers assessment on the following components:

a. Earnings;

b. Capital structure;

c. Cash flow; and

d. Sensitivity to market risk.

3. Assessment of repayment capability as referred to in Article 10 letter c covers assessment on the following components:

a. Timeliness of payments of principals and interests;

b. Availability and accuracy of debtor's financial information;

c. Completeness of credit documentation;

d. Compliance with the credit agreement;

e. Appropriateness of the use of funds; and

f. Reasonableness of source of payment for obligation."

7. Elucidation of Bank Indonesia Regulation Number 14/15/PBI/2012 concerning Assessment of Commercial Bank Asset Quality, at the Article 11 Paragraph 1 letter e stated that, "In this letter, debtor means debtor that is obliged to make efforts to maintain the living environment in accordance with prevailing legislation."

8. The Financial Services Authority Regulation Number 51/POJK.03/2017 concerning The Application of Sustainable Finance for Financial Services Institutions, Issuer Companies, and Public Companies. In the Considering 
part, Letter c states that, "whereas the development of an environmental-friendly financial institution system has been mandated in Act Number 32 of 2009 regarding Environmental Protection and Management."

9. Article 1 Point 8 of the Regulation of Financial Services Authority Number 51/POJK.03/2017 concerning The Application of Sustainable Finance for Financial Services Institutions, Issuer Companies and Public Companies states that, "Sustainable finance shall be comprehensive support from the financial services sector to create sustainable economic growth by harmonizing economic, social, and environmental interests."

10. Article 1 Point 11 of the Regulation of Financial Services Authority Number 51/POJK.03/2017 concerning The Application of Sustainable Finance for Financial Services Institutions, Issuer Companies and Public Companies states that, "Sustainable Finance Action Plan shall be a written document illustrating short-term (one year) and long-term (five year) FSO business activity plan and work program that is in accordance with the principles used for applying Sustainable Finance, including strategies for realizing the aforementioned plan and work program in accordance with the stipulated targets and time, by consistently observing compliance with the provisions on prudential principle and the application of risk management."

11. Article 1 Point 13 of the Regulation of Financial Services Authority Number 51/POJK.03/2017 concerning The Application of Sustainable Finance for Financial Services Institutions, Issuer Companies and Public Companies states that, "Sustainability Report shall be a report announced to public containing the economic, financial, social and environmental performance of FSI, Issuer company or public company in running sustainable business."

12. Article 2 Paragraph (2) of the Regulation of Financial Services Authority Number 51/POJK.03/2017 concerning The Application of Sustainable Finance for Financial Services Institutions, Issuer Companies and Public Companies states that, "The Sustainable Finance application as referred to in paragraph (1) shall be performed by using:

a. Accountable investment principle; 
b. Sustainable business strategy and practice principle;

c. Social and environmental risk management principle;

d. Management principle;

e. Informative communication principle;

f. Inclusive principle;

g. Priority prime sector development principle; and

h. Coordination and collaboration principle."

13. Article 10 Paragraph (1) of the Regulation of Financial Services Authority Number 51/POJK.03/2017 concerning The Application of Sustainable Finance for Financial Services Institutions, Issuer Companies and Public Companies states that, "FSIs, Issuer Companies, and Public Companies shall be obligated to prepare a Sustainability Report." Furthermore in Paragraph (2) states that, "The Sustainability Report as referred to in paragraph (1) shall be prepared separately from the annual report or as an inseparable part of the annual report."

14. Article 12 Paragraph (3) of the Regulation of Financial Services Authority Number 51/POJK.03/2017 concerning The Application of Sustainable Finance for Financial Services Institutions, Issuer Companies and Public Companies states that, "For the FSIs not yet having websites, the Sustainability Report must be published through a printed media or any other publication media easily read by public by no later than April 30 of the subsequent year."

Although the bank has appraised AMDAL of its client before the financing approved as regulated in the prevailing laws, the bank is not liable in relation to the business activity of the client which is being financed. As reported by NGOs (among others: Greenpeace, WALHI, and WWF) as explained in the background of this research, many banks fund palm oil companies involved in burning peatlands and forest degradation regardless they should implement the environmentally sound policy, such No Deforestation, No Peat, and No Exploitation (NDPE). The NGOs compel the banks to take responsibility for environmental damage caused by their clients because the banks are deemed to 
know the client's business activities based on the AMDAL required by the bank before the loan application is approved. After NGOs compel the banks to take responsibility, they promised to be more selective, stop financing, and improve their funding and credit policies.

\section{CONCLUSION AND RECOMMENDATION}

\section{Conclusions}

a. Based on the aforementioned discussion, the identification of Green Banking concept and bank's liability can be found in the Act Number 10 of 1998 concerning Banking, Act Number 32 of 2009 concerning Environmental Protection and Management, the Bank Indonesia Regulation Number 14/15/PBI/2012 concerning Assessment of Commercial Bank Asset Quality, and the Financial Services Authority Regulation Number 51/POJK.03/2017 concerning The Application of Sustainable Finance for Financial Services Institutions, Issuer Companies, and Public Companies. By using extensive interpretation and progressive legal approach actually, there are several provisions (in the Act Number 10 of 1998 concerning Banking, Bank Indonesia Regulation Number 14/15/PBI/2012 concerning Assessment of Commercial Bank Asset Quality, Financial Services Authority Regulation Number 51/POJK.03/2017 concerning The Application of Sustainable Finance for Financial Services Institutions, Issuer Companies, and Public Companies, and Act Number 32 of 2009 concerning Environmental Protection and Management) that have been regulated regarding green banking concept and bank's liability, substantially derived from prudential principle.

b. So far, the concept of green banking and the bank's liability as lender for client's company involved in the environmental destruction is still difficult to be implemented by the banking sector in Indonesia, in other words, depending on the ability of the bank itself. The burden of bank's liability will be even greater when it is subject to environmental risks and the adverse impact of the client's business, while at the same time, the bank must maintain its safety and soundness by maintaining the capital adequacy that 
buffers such risk. If the bank is responsible for the risk of environmental damage committed by its client, then it drastically reduces bank's capital adequacy, which ultimately affects the soundness of the bank.

c. Most of the banks have no willingness to further scrutinize and supervise Environmental Impact Assessment (AMDAL) in financing significant risky businesses such as some oil palm plantation companies recently sued by many NGOs due to deforestation, other environmental and social issues. Such AMDAL is insufficient for helping mitigate the environmental destruction. The voluntary Environment, Social, and Governance (ESG) Standards that banks have adopted to prevent exposure to environmental destruction caused by their borrowers are clearly ineffective. By taking into force the Financial Services Authority Regulation Number 51/POJK.03/2017 concerning The Application of Sustainable Finance for Financial Services Institutions, Issuer Companies and Public Companies that promulgated on July 27, 2017, is hoped for realizing the concept of green banking and the scope of bank's liability as lender in pursuit of sustainable finance.

d. It remains unclear to what extent bank liability as financier (lender) involved in the environmental damage caused by their clients. If the bank only requires AMDAL without further supervision, then the liability of the bank to be limited when applying credit only. Meanwhile in CERCLA (SARA) applied in the United States, the liability of the lender may be imposed on the bank if the bank has the role of owner, operator and/or participate in the management of the client company.

\section{Recommendations}

a. Implementing the existing provisions in Act Number 10 of 1998 concerning Banking, Bank Indonesia Regulation Number 14/15/PBI/2012 concerning Assessment of Commercial Bank Asset Quality, Financial Services Authority Regulation Number 51/POJK.03/2017 concerning The Application of Sustainable Finance for Financial Services Institutions, Issuer Companies and Public Companies, and Act Number 32 of 2009 concerning Environmental Protection and Management should be done by extending the understanding 
of Green Banking concept and bank's liability by means of extensive interpretation and progressive legal approach.

b. Short term solution: The Financial Services Authority (OJK) and the banking sector together with the Ministry of Environment and Forestry improve soft law such as Road Map or Guidelines on Green Banking into hard law. With the enactment of the Financial Services Authority Regulation No.51/POJK.03/2017 concerning the Application of Sustainable Finance for Financial Services Institutions, Issuers Companies and Public Companies, all parties involved in the business chain must comply with the Prudential Principle and Precautionary Principle for sustainability itself. Strengthening cooperation between the Financial Services Authority (OJK) and the Ministry of Environment and Forestry to monitor the efforts of bank clients in preserving the environment, they must deliver the accuracy of data and public transparency. Data transparency is a prerequisite for the development of green banking.

c. Conventional media and websites should inform the green banking implementation procedures and feedback from customers and the public, for example about tax schemes for institutions with good environmental performance. By incorporating and announcing the gradual implementation of green banking that has been carried out by a number of banks to OJK and Bank Indonesia website pages and other conventional media, this progress will be a boost for banks and other financial institutions. Green banking practices, especially those involving large-scale and high-risk projects, have a wide-ranging impact on society and environmental sustainability in which their survival depends on nature conservation, and this can be supported by the bank's important role as a financier or lender.

d. Medium term solution: legislative review of Act Number 10 of 1998 in order to implement environmentally sound banking law. Whether the banks are responsible for environmental damage caused by their clients, therefore banks are responsible for minimizing risks. Another driving forces are the changing public expectations, market demand challenges and opportunities which move 
towards sustainability such as wind energy, solar energy, forests conservation, smart villages, and so forth.

e. Long term solution: integrated monitoring and evaluating among relevant stakeholders such as banks and other financial institutions, Financial Service Authority (OJK), Bank Indonesia, ministries, Non-Government Organizations, corporations, consumers, competitors, media, suppliers, and widely communities. It can be increasing consumers awareness to use their rights as customers for getting more information about their savings, deposits, and other usages of public funds held in banks whether those are still used for financing companies that are not environmentally friendly. From here, we can measure what the extent of bank's commitment to apply the concept of green banking.

\section{BIBLIOGRAPHY}

\section{Laws, and Regulations}

Act Number 7 of 1992 concerning Banking (State Gazette of the Republic of Indonesia Number 31 of 1992, Supplement to the State Gazette of the Republic of Indonesia Number 3472) as amended by Act Number 10 of 1998 (State Gazette of the Republic of Indonesia Number 182 of 1998, Supplement to the State Gazette of the Republic of Indonesia Number 3790)

Act Number 32 of 2009 concerning Protection and Environmental Management. Supplement to the State Gazette of Republic of Indonesia Number 5059.

Act Number 12 of 2011 concerning Formulation of Regulatory Legislation.

(Supplement Number 5234 to the State Gazette of the Republic of Indonesia Number 82 of 2011).

Bank Indonesia Regulation Number 14/15/PBI/2012 concerning Assessment of Commercial Bank Asset Quality. Supplement to the State Gazette of the Republic of Indonesia Number 5354.

Financial Services Authority Regulation Number 51/POJK.03/2017 concerning The Application of Sustainable Finance for Financial Services Institutions, Issuer Companies, and Public Companies. (State Gazette of the Republic of Indonesia Year 2017 Number 169). 


\section{Books}

Marzuki, Peter Mahmud. 2007. Penelitian Hukum. Kencana. Jakarta.

Soekanto, Soerjono. 1986. Pengantar Penelitian Hukum. Penerbit Universitas Indonesia (UI-Press). Jakarta.

\section{Journal, Report and Article}

General Assembly. United Nations. A/CONF.151/26 (Vol.I). "Report of The United Nations Conference on Environment and

Development." Rio de Janeiro, 3-14 June 1992. http://www.un.org/documents/ga/conf151/aconf15126-1annex1.htm. Accessed on July 14, 2017.

Imammulhadi. "Perkembangan Prinsip Strict Liability dan Precautionary dalam Penyelesaian Sengketa Lingkungan Hidup di Pengadilan." Mimbar Hukum. Volume 25, No.3. October 2013. Page 430. https://jurnal.ugm.ac.id/jmh/article/viewFile/16070/10616. Accessed on July 13, 2017.

\section{Internet}

Equator Principles Association Members and Reporting. 2011. http://www.equator-principles.com/index.php/members-and-reporting. Accessed on April 12, 2017.

Forests and Finance. "The Banks and Investors Exposed to Deforestation Risks in Southeast Asia, 2010-2015." http://forestsandfinance.org/ Accessed on January 24, 2017.

"The Banks and Investors Exposed to Deforestation Risks in Southeast Asia." 2016. http://forestsandfinance.org/

\section{Dictionary}

Black's Law Dictionary. Eight Edition. Editor in Chief. Bryan A. Gardner. 2004. Thomson West. United States of America. 